\title{
Franciaország vagy függetlenség? Új-Kaledónia és a függetlenségi népszavazás
}

\author{
France or Independence? \\ The New Caledonian Independence Referendum
}

Wiszl Diana

https://doi.org/10.47707/Kulugyi Szemle.2021.2.4

Összefoglaló: Új-Kaledónia közeledik a Nouméa-egyezmény értelmében tartandó harmadik, egyben utolsó függetlenségi népszavazásához. Az 1998-as megegyezés immár 23 éve biztosítja a békét a szigeten. Az önrendelkezési folyamatáról szóló első két történelmi választás során (2018-ban és 2020-ban) a szavazók enyhe többsége adta le a voksát a Franciaország tengerentúli területe (speciális közösségi) státusz fennmaradása mellett, ám az eredményeken megmutatkozott a tartós etnikai megosztottság - ami bizonytalan jövőképet vetített előre, és növelte a stabilitást veszélyeztető kockázatokat. A lojalistáknak és a függetlenségpártiaknak - a 2021. december 12-én esedékes referendum eredményétől függetlenül - párbeszédet kell kezdeniük a régóta fennálló nézeteltérések megoldása és a békés kormányzás folytatásának a biztosítása érdekében.

Az elemzés Új-Kaledónia múltjára és jelenére igyekszik rávilágítani - a kontextusra, amelyből a mostani helyzet kibontakozott -, valamint megvizsgálja az első két választás eredményét. Emellett górcső alá veszi, hogy a ma érzékelhető társadalmi nyugtalanság milyen hatással lehet a régió stabilitására, és a szigetország miért is bír kulcsfontosságú stratégiai jelentőséggel Franciaország és Kína számára.

Kulcsszavak: Új-Kaledónia, Franciaország, függetlenség, népszavazás, kanak, Nouméa

Abstract: New Caledonia is approaching the last referendum of three such voles on its self-determination process under the Nouméa Accord, that has overseen peace in the island for almost two and a half decades. During the first two historic referendums in 2018 and in 2020, slight majority of the volers decided to remain with France; however, the results reveal a persistent ethnic divide over 
independence, indicating uncerlain future and strengthening risks to stability. Regardless of the outcome of the third vote that will take place on 12 December 2021, loyalists and independentists need to start dialogues in order to resolve the differences and ensure the continuation of peaceful governance.

This paper seeks to shed light on the past and present of New Caledonia, the context in which the present siluation had unfolded, examines the results of the past two voles, while also looking at how the ongoing social unease may influence the stability of the region, as well as why the archipelago is a key strategic interest for France and for China.

Keywords: New Caledonia, France, independence, referendum, kanak, Nouméa

\section{Bevezetés}

A James Cook kapitány által felfedezett és Skócia után elnevezett dél csendes-óceáni Új-Kaledónia 1853 óta tartozik hivatalosan Franciaországhoz; mára az egyik legfontosabb francia tengerentúli terület, amely sui generis státuszt visel. Új-Zéland és Pápua Új-Guinea után a harmadik legnagyobb szigetcsoport a térségben: a fösziget hossza 400, szélessége $50 \mathrm{~km}$. Stratégiai elhelyezkedése és nyersanyagkészlete miatt a megtartása kulcsfontosságú Franciaország számára. Ma gas hegyei értékes nikkel- és krómkészleteket rejtenek; egyes becs lések szerint a világ nikkelkészletének negyede a szigeten található. A teljes földterülete $18.564 \mathrm{~km}^{2}$ (New Caledonia Travel, é. n.), a kizárólagos gazdasági övezete 1,3 millió $\mathrm{km}^{2}$-nyi területre terjed ki (Pew Trusts, é. n.), ezzel Új-Kaledónia révén Franciaország a világ második legnagyobb kizárólagos gazdasági övezetével rendelkezik (The Economist, 2016). Őslakosai a kanakok. A 2019-es népszámlálási adatok (ISEE, 2019) alapján a szigetcsoport 270 ezer lakosának 41 százaléka vallja magát kanaknak; az európaiak a népesség 24 százalékát adják, a fennmaradó 35 százalékot az egyéb etnikumú (polinéz, malinéz, indonéz, vietnami stb.) népesség teszi ki.

A szigetek a francia gyarmatosításuk (1853) után viszonylag rövid idôn belïl fegyencteleppé váltak, egyúttal az érckészlet felfedezését követően nagy ütemú kitermelés vette kezdetét. Mivel várható volt, 


\section{Külïgyi Szemle}

hogy az őslakosok tiltakozni fognak, a franciák - a sziget mindössze 10 százalékát kitevő - rezervátumokba kényszerítették a kanakokat (Winslow, 1991). Az erőszakos gyarmatosításra válaszul 1878-ban felkelés tört ki. Az őslakosok 1887-től a bennszülött törvény (Code de lindigénat) alá tartoztak, és ez a szegregáció a második világháború végéig fennmaradt. A kanakok nem szavazhattak, a gyerekek nem tanulhattak az anyanyelvüikön, állami oktatásban is csak korlátozottan részesülhettek. 1946-ban az addig gyarmati státuszú Új-Kaledóniából Franciaország tengerentúli területe lett, de a jogokat csak fokozatosan terjesztették ki rájuk: 1951-től végre az őslakosok is szavazati jogot szereztek, 1953-ban pedig a sziget minden lakója francia állampolgárságot kapott, emellett kimondták a szabad költözés jogát is.

Az első függetlenségi népszavazást 1958-ban tartották (République Française, Légifrance, 1958), s azon a szavazók 98 százaléka a Franciaországhoz tartozás mellett döntött, ezzel egyidejúleg a Kaledón Unió, Új-Kaledónia akkori egyetlen pártja további autonómiát kért Párizs tól. A következó évek során felgyorsult a nikkel kitermelése, új küllföl di partnerek jelentek meg. Franciaország, hogy megerősítse a terü leten játszott szerepét, nyílt bevándorlási politikát folytatott annak érdekében, hogy fokozatosan többségbe kerüljenek a maradáspártiak a szeparatistákkal szemben. Ahogy az akkori francia miniszterelnök fogalmazott (ICRA International, 2018): „hosszú távon a bennszülött nacionalista követelés csak úgy kerülhető el, ha a nem őshonos közös ségek alkotják a demográfiai többséget”.

A második világháborútól kezdődően fokozatosan újabb erôt ka pott kanak füiggetlenségi mozgalom fơ célja a földtulajdon visszaszol gáltatása és az oktatás reformja volt; Kanak Népiskola néven saját is kolahálózatot is kiépítettek. A következő évtizedekben Párizs tíz olyan törvényt alkotott, amely jelentősen bővítette a helyi autonómiát. Az 1970-es évek végére megosztottá vált a még mindig egyetlen politikai formáció, a Kaledón Unió. A szeparatisták Kanak Szocialista Nemzeti Felszabadítási Front (Front de Libération Nationale Kanak et Socialiste, FLNKS) néven alapítottak pártot, és fő célukul a bevándorlás csökkentését, valamint a nikkelből származó bevételek újraelosztását tưzték 
ki. Velük szemben megjelent a lojalista párt (Rassemblement pour une Calédonie dans la République, RPCR), amely a Franciaországhoz tartozásért küzd. Az FLNKS az újonnan függetlené vált szomszédos szigetállamoktól is komoly támogatást kapott, amelynek megerősíté sére és a térségbeli dekolonizációs politikák miatti aggodalmak követ keztében alakult meg a Csendes-óceáni Fórum (Fisher, 2018), amely mára a régió egyik legfontosabb politikai szervezete lett.

A szocialista François Mitterrand 1981-es megválasztásától a kanak szeparatista mozgalom új esélyt várt a céljaik véghezviteléhez,a reményeik azonban nem igazolódtak be: az általuk kikiáltott Kanak Szocialista Köztársaságot senki sem ismerte el. A feszültség megállíthatatlanul növekedett az etnikai csoportok között, és az 1980-as évek közepére a területen egyfajta polgárháborús helyzet alakult ki. Fran ciaország javaslatára 1987-ben megtartották a második függetlenségi népszavazást (France24, 2018), miután az ENSZ Új-Kaledóniát visz szatette a gyarmati területek listájára. A szeparatisták a szavazói lis tát nehezményezték a legfőképpen, ugyanis azok az állampolgárok is jogosultak voltak a választásra, akik csupán 3 éve tartózkodtak a területen, ami jelentősen csökkentette az őslakosok befolyását. Emellett az is komoly problémát jelentett, hogy Párizs eleinte nem támogatta, hogy az ENSZ megfigyelői is ellenőrizhessék a folyamatot. A bojkott ellenére 59 százalékos részvétellel megtartott választáson kevesebb mint 2 százalék szavazott a füiggetlenségre. Ez a csalódottság 1988 ra kulminálódott: a kanakok megtámadták a francia rendőröket, és túszokat ejtettek Ouvéa-szigeten fekvő gossanahi barlangban (APR Editor, 2018). A több emberéletet is követelő konfrontáció, valamint a Franciaország-ellenes regionális kampány sikere végül párbeszédre kényszerítette a nagyhatalmat.

Párizs a két párt vezetőjével, Jean-Marie Tjibaou-val (FLNKS) és Jacques Lafleurrel (RPCR) 1988 nyarán aláírta a Matignon-Oudinot egyezményt (Philippon és Gnipate, 2018). A megállapodással létrejött a jelenlegi tartományi felosztás (Déli, illetve Északi tartomány, továbbá a Lojalitás-szigetek), valamint függetlenségi népszavazást tűztek ki 1998-ra, amelyre korlátozott listát állítottak, így azon csak azok 


\section{Külïgyi Szemle}

jogosultak a voksolásra, akik 1988-ban már a szigeten laktak, illetve az utódaik. Az egyezmény kitért a másik nagy problémára is: kitűzte a nikkeltermelés és az abból származó bevételek úijraelosztását. A tíz éves átmeneti időszak során Új-Kaledónia autonómiája fokozatosan bőviult, és úgy tủnt, a területre béke és gazdasági fejlődés vár.

Az egyezmény megvalósítása azonban nem volt problémamentes. Kevesebb mint egy évvel a szerződés megkötése után egy radikális szeparatista kanak meggyilkolta a békére törekvő függetlenségi ve zetőt, a mozgalom vezéralakját, Jean-Marie Tjibaou-t. A feszültség nem csökkent, ezért 1991-ben a vezetők a népszavazás elhalasztásáról hoztak döntést, mert attól tartottak, hogy a bizonytalan és ingatag helyzet újabb polgárháborút szülne. Míg a szeparatisták azt remélték, hogy az átmeneti időszak alatt elég tapasztalatot gyújthetnek a függetlenné váló ország irányításához, addig a lojalisták abban bíztak, hogy a következő évek gazdasági fejlődése és az újraelosztás meggyőzi a kételkedőket is arról, hogy biztonságos jövő csak Franciaország mellett lehetséges. Az említett vezetỏi döntést az 1998. május 5-én aláirt Nouméa-megállapodással (République Française, Légifrance, 1998) tették hivatalossá, amelyben 2018-at túzték ki a népszavazás legvégső határidejeként. Ez az egyezmény ismerte el elsóként a kanak identitást, létrehozta a kongresszust, kezdeményezte a hatalom viszszafordíthatatlan átruházását Új-Kaledóniára - a honvédelem, a nemzetbiztonság, a külügy, az igazságszolgáltatás és a pénzügy kivételével, amelyek felett továbbra is Párizs rendelkezik. Emellett a terület sui generis státust kapott.

Az emlitett két megállapodás összesen három évtizedig biztosította a fejlődést és stabilitást a területen. Új-Kaledónia - és főleg a fővárosa, Nouméa - mára a térség gazdaságilag egyik legfejlettebb területe lett. A szigetcsoporton magas az életszínvonal, az egy före jutó GDP a csendes-óceáni térségben a legmagasabbak között van: 2018-ban átlagosan 38.270 dollárnak felelt meg (Mcdonald, 2020). A növekvő egyenlőtlenségek (Goulard, 2018) azonban egyre nagyobb feszültséget okoztak, így nagyon fontos cél lett a gazdasági egyensúly helyreállitása is. A bányászat fellendülésével a teljes népesség 
életszínvonalának kellett volna javulnia, ehelyett a bérolló tovább nőtt. A fiatalok 36 százaléka munkanélküili, a megélhetési költségeket pedig az import és a nikkeltől való gazdasági függés egyre feljebb nyomja. 2008-ban a lakosság 17 százaléka ragadt a szegénységi küiszöb alatt, s ez az arány azóta sem javult. A mai napig nagyon sok problémát okoz, hogy a kanak fiatalokat nem sikerül integrálni sem a gazdasági életbe, sem az oktatási rendszerbe, ez pedig szórványos erôszakhoz, lemorzsolódáshoz, drogok használatához vezet, főleg Nouméa St. Louis nevű negyedében. Egy ENSZ-jelentés szerint a kanakok társadalmi helyzete kétségbeejtő, zömében szegénységben élnek, és megfelelő iskolai végzettség nélkül a foglalkoztatásban is alig vesznek részt; a változásnak alig vannak jelei (Human Rights Council, 2011).

\section{A 2018 -as és a 2020-as referendum}

Az erősödő politikai megosztottság és a továbbra is fennálló társadalmi nyugtalanság miatt rögös volt az út a népszavazás kitúzéséig. A küiönbségek egyre jobban kiéleződtek, a szavazás komoly kockázati tényezőket rejtett magában. A kongresszus az egyezmény alapján lehetséges legkésőbbi időpontra, 2018. november 4-re tủzte ki az első választás megtartását. A Nouméa-egyezmény kimondja, hogy amenynyiben az első népszavazáson többségbe kerülnek az elszakadást támogató szavazatok, a kongresszus egyharmadának a jóváhagyásával két éven belïl újabb szavazást lehet tartani (Dayant, 2018). Nemleges döntés, vagyis a Franciaországban maradás esetén három népszavazást engedélyeztek, azzal a kikötéssel, hogy ha mindegyik eredménye „nem”, a pártoknak párbeszédet kell folytatniuk a fennálló problémák megoldása érdekében. Az egyezmény legfőbb célja, hogy az erőszak minden formájának elejét vegyék, ennek érdekében kétéves átmeneti periódusnak kell követnie a szavazásokat; így - a harmadik referendum eredményétől függően - 2023-ban vagy kiáltja a függetlenségét a terület, vagy egy negyedik szavazás zárja le és véglegesíti a folyamatot (Roger, 2021). 


\section{Külïgyi Szemle}

Új-Kaledónia az önrendelkezést célzó folyamata során az elsỏ két népszavazáson elutasította a függetlenséget. 2018-ban 56,7 százalék tette le a voksát az anyaország mellett, és 43,3 százalék szavazott az elszakadásra (Tromeur, 2019). A döntés nem volt váratlan, hiszen az előzetes közvélemény-kutatások jelentős különbséget jeleztek a két tábor között (Peteisi, 2020), azonban a magas, 81 százalékos részvételi arány és az elszakadás ilyen nagyarányú támogatottsága meglepetés volt. Az eredmény a kongresszusban meglévő egyensúlyt is tükrözte. A 2020. október 4-i, második népszavazás is a függetlenség ellenzőinek a többségét bizonyította (53,26\%), az etnikai alapú függetlenség támogatása azonban nem várt módon megerősödött: 46,74 százalék szavazott rá igennel. A részvételi arány tovább nőtt, 85,6 százalékra; ez a több mint 4 százalékos növekedés egyértelmúen a függetlenségi pártoknak volt köszönhető. Míg 2018-ban az igenek és a nemek között 18.000 szavazat különbség volt, ezt a függetlenségi pártok majdnem a felére, 10.000 szavazat alá csökkentették (Commission de contrôle, 2020).

A szavazásra jogosult választópolgárok listája évek óta a vita kö zéppontjában áll: mindkét fél vitatja a legitimitásukat. 2015-ben a kép viselók az ENSZ-hez fordultak jogorvoslatért. Az állításuk beigazoló dott: a nemzetközi szervezet megállapította, hogy a francia felügyeleti bizottságok valóban a lojalistáknak kedveztek. Ennek elkerülése érde kében 2016-ban és 2017-ben az ENSZ delegáltjai is részt vettek a lis ta előkészitési folyamatának a felïgyelésében. Az egyezmények pedig kimondják, hogy minden kanaknak joga van a függetlenségi népszavazáson való részvételre, a más etnikumokhoz tartozóknak viszont 2014-et megelózően legalább 20 éves ott-tartózkodást kell bizonyítaniuk.

A szeparatisták - a vártnál kisebb 2018-as különbségen felbátorodva megerősitették a helyzetuiket (a kongresszusban is), a maradáspártiakat azonban tovább gyengíti a fokozatos fragmentáció; a pártjaik számára egyértelmű kihívást jelent az együttmúködés. A függetlenségpártiaknak a kampánystratégiája meglepően sikeresnek bizonyult az ifjúság körében (Dayant, 2020a). A közösségi média sikeres használatával nemcsak a kanak, hanem általában az új-kaledóniai fiatalokat is elérték: 
közülüik sok első szavazót is meggyőztek a függetlenség szükséges ségéről. A 2020-as népszavazáson a részvétel növekedése szintén a szeparatistáknak kedvezett, ugyanis azoknak, akik a korábbi referendumon tartózkodtak, a többségüik ez alkalommal a függetlenség mellett adta le a voksát. A második választáson az „igen” szavazatok aránya több mint 3 százalékkal nőtt meg, ami 11 ezerrel több szavazatot jelentett.

\section{1. ábra}

Az új-kaledóniai 2020-as függetlenségi népszavazás eredményének terïleti eloszlása

\section{Csökken a szavazatok közötti különbség}

«Szeretné, ha Új-Kaledónia teljes szuverenitást szerezne

és függetlenné válna?»

Részvételi eredmények (\%)

Népszavazás

2018. november 4

\begin{tabular}{c|cc} 
Igen & $\mathbf{4 6 , 7} \%$ & $43,3 \%$ \\
Nem & $\mathbf{5 3 , 3} \%$ & $56,7 \%$
\end{tabular}
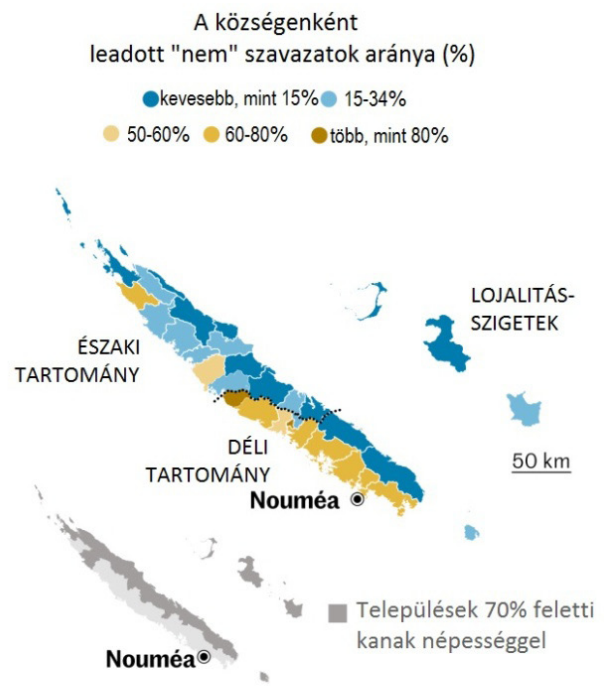

Infográfia Le Monde Forrás: Francia Belügyminisztérium Megjegyzés: kék: függetlenségpártiak; zöld: maradáspártiak.

1 Forrás: Roger, 2020. 


\section{Külïgyi Szemle}

Ami biztosan látszik, az az, hogy a szavazási minták megdermedtek, s egyik fél sem tudta jelentősen megerősíteni a szavazóbázisát. A referendum etnikai, földrajzi és társadalmi jellegét (Dayant, 2020b) a második népszavazás eredménye is visszatükrözte - e megosztottság Új-Kaledónia politikai hátteréből fakad. Általánosságban elmondható, hogy azokon a településeken, ahol magasabb a kanak lakosok aránya (Északi tartomány és a Lojalitás-szigetek), határozott igennel szavaznak (80-90 százalék) a függetlenség mellett, míg a nemleges szavazat a legnépesebb és leggazdagabb Déli tartományban élő többnemzetiségú közösségekben mutatott hasonlóan magas rátát. Nouméában a függetlenség ellen 70,86 százalék szavazott. Kivételek ott is vannak, s nem minden kanak támogatja a függetlenséget - ahogy a többi etnikum sem feltétlenül maradáspárti. A függetlenségpártiak ugyanakkor az Új-Kaledónián kívüli területekre is ki akarják terjeszteni a szavazójogot: klánkapcsolatokra hivatkozva missziókat indítottak a környező szigetekre - ahol a lakosság körülbelül 39 százalékát a kanakok adják -, hogy ők is szavazhassanak. Különösen a Melanéziai Lándzsahegy Csoport nevû szervezet támogatja az elszakadást.

Az ismertté vált adatok szerint az eddigi tartózkodók földrajzilag éppen a függetlenségpárti területekről kerülnek ki, s ez esélyt adhat a két fél szavazatai közti különbség csökkentésére - azonban a szeparatisták csak akkor tudják behozni a lemaradásukat, ha sikerül meggyőzniük a tartózkodókat a részvételük fontosságáról, és csökken a lojalisták elkötelezettsége. A demográfiai adatok szintén a függetlenségpártiaknak kedveznek, ugyanis az először szavazó kanak fiatalok száma egyre növekszik, a többi etnikumé viszont folyamatosan esik vissza. Fontos megemlíteni azonban, hogy bár a kanak népesség egyre jelentősebb arányúvá válik, a nem őslakosok összességében továbbra is többséggel rendelkeznek a területen. 


\section{Jövőkép}

A szavazás körüli napokban, hetekben jelentősen megnő a társadalmi nyugtalanság, aggasztóak a hetekig tartó tüntetések. A megszaporodik a gyújtogatások és az útblokádok száma, a rendőrség közbeavatkozása szüikséges és elkerülhetetlen. Mindez a francia kormány szerepvállalásának a hiányából is fakad. Párizs nincs könnyű helyzetben: egyszerre a döntőbírója, a megfigyelője és a résztvevője a folyamatnak, megfelelni pedig egyik félnek sem tud. A függetlenségpártiak szerint a francia kormány kivételez lojalistákkal (2018-ban például a kampányanyagaikon szerepeltethették a francia trikolort - a brosúrákat akkor be is tiltották), eközben a lojalisták azt nehezményezik, hogy az új francia miniszterelnök, Jean Castex kinevezése óta lazábbá vált a kapcsolat Franciaország és Új-Kaledónia között. A francia médiaérdeklődés az elmúlt két évben feltűnően megesappant, amit a lojalisták cserbenhagyásnak élnek meg. Emmanuel Macron és Jean Castex egyaránt hallgatásba burkolózott a második kampány alatt, s azt hangsúlyozták, hogy a helyi kongresszuson múlik a döntés. A helyzet kiéleződésével azonban Franciaország is elkezdte komolyan venni Új-Kaledónia füiggetlenségének a lehetőségét, így a két kormány képviselői 2021. június elején, Párizsban, tárgyalásokat folytattak a jövőbeli kétoldalú kapcsolataikról. A lehetséges füiggetlenségnek az immár nem tabuként történő kezelése jelentős változás a kormányzati stratégiában, amely dominóeffektust indíthat el.

A francia kormány évente 1,3 milliárd euróval járul hozzá Új-Kaledónia költségvetéséhez (Kelly, 2020), s ezzel a GDP-je több mint 15 százalékát biztosítja. Függetlenség esetén ez a támogatás is megszűnne. A lojalisták az 1980-ban függetlenné vált Vanuatu példájával igyekeznek meggyőzni a kételkedőket, hogy szuverén országként a jövőben Új-Kaledóniára is az elkerülhetetlen elszegényedés várna. „Nem élhetünk francia pénz nélkül” - érvelnek a maradáspártiak. A szeparatisták viszont úgy vélik, a nikkelbányászat helyi ellenőrzése elősegíti a független nemzet megalapozását. A fémet elsősorban rozsdamentes acél készítésére használják, azonban mivel az elektromos 


\section{Külïgyi Szemle}

jármúvekben használt legerősebb lítiumion-akkumulátorokhoz is nik kelre van szüikség, a kereslet várhatóan növekedni fog. A szigetcso port a világ ötödik legnagyobb nikkeltermelője (Australian Trade and Investment Commission, é. n.) Indonézia, a Fülöp-szigetek, Oroszor szág és Ausztrália után (Herlelendi Müvek, 2021). Az ipar kulcsfon tosságú Új-Kaledónia gazdasága szempontjából: a küllföldi bevételei zömét az adja. Az első számú exportpiaca Kína, amely 2019-ben több mint 1 milliárd dollár értékben vásárolt nikkelt (OEC. The Observatory of Economic Complexity, 2019), de a szigetcsoporton elöállított ferronikkel 72 százaléka is az ázsiai óriásnál köt ki (Jeannin, 2020).

A sziget déli részén található Goro-bánya potenciálisan a világ egyik legnagyobb nikkeltermelője lehet, azonban a veszteséges múködése miatt 2020 decemberében a francia állam és a tulajdono sok megpróbálták eladni a svájci Trafigurának (Maclellan, 2020). Az tranzakció nemcsak heves ellenállást váltott ki a függetlenségpárti csoportokból, de Új-Kaledónia kormányának összeomlását is maga után vonta (Barrett, 2021). Végüil a több hónapos tárgyalás után kialakított feltételekkel 2021 márciusában az újonnan megválasztott - egyben az első, függetlenségi pártok által uralt - kabinet megálla podást kötött az üzem jövőjéről. Az egyezménnyel végre megoldód ni látszik a terület egyik legfontosabb, az 1960-as évek óta fennálló problémaköre is, és megtörtént a békés jövő biztosításának a legfontosabb lépése: Új-Kaledónia értékes nikkelkészleteinek a tulajdonlása, a kapcsolódó tevékenységek irányítása és a bevételek újraelosztása. Mindez nemesak a szeparatista és a lojális csoportok közti, hanem a francia kormánnyal folytatandó együttmúködés révén is lehetőséget nyúijt a békés fejlődésre és gazdasági gyarapodásra. Az új megálla podás szerint a szigetcsoport 51, a svájci székhelyű Trafigura 19, a Prony Resources pedig 30 százalékos részesedéssel bír az üzemben; továbbá a szerződés szigorúbb környezetvédelmi normák betartását követeli meg, és karbonsemlegességet tûz ki 2040-re (Sanderson, 2021). Habár nem részvényesként, de ipari tanácsadóként a Tesla is részt vesz az üzletben: segíti a környezeti fenntarthatóság javítását, valamint a gyártás, szállítás és tárolás folyamatának az átalakítását. 
Az új amerikai partnerségnek köszönhetően előreláthatólag Új-Kale dónia nikkeliparának a Kínától való függése is csökkenni fog.

A Nouméa-egyezmény értelmében 2022-ig döntést kell hozni Új Kaledónia jövőjéről (Fisher, 2020), az eddigi tapasztalatok pedig azt mutatják, hogy az eredmény még szorosabb lesz a következő választá son, 2021. december 12-én. Amennyiben akkor az elszakadást támogatók kerülnek többségbe, egy meghatározott átmenet után Új-Kale dónia független lesz. A megosztottság és a társadalmi nyugtalanság miatt azonban a szavazás eredményétôl füiggetlenül kritikus fontosságú lesz a párbeszéd. Az ENSZ dekolonizációs alapelvei szerint négy lehetőség áll a terület előtt: függetlenség, kétféle partnerség, illetve a Franciaországhoz tartozás.

\section{Regionál is következmények}

Bármilyen eredménnyel is zárul a referendumfolyamat, annak stratégiai következményei lesznek mind Franciaországra, mind a csendes-óceáni régióra. Párizs számára nagy a tét: a térségben jelen levő utolsó európai hatalomként igen fontos a jövő szempontjából, hogy megtartsa a stratégiai jelentőséggel bíró Új-Kaledóniát (Fisher, 2013, 29. o.). A szigetcsoportot annak földrajzi elhelyezkedése és jelentôs nikkelkészlete következtében politikai és gazdasági eszközként is fel tudja használni. Azonban döntőbíróként, érdekeltként és Új-Kaledónia politikájának résztvevőjeként nines könnyủ helyzetben: fenn kell tartania a semlegességét, miközben egyértelmú érdeke a terület megtartása. A szigetek birtoklásával Párizs teljes körű legitimitást élvezhet csendes-óceáni hatalomként is. Ezáltal nem csupán a tagja maradhat a Csendes-óceáni Közösségnek, de a nagyhatalmi szerepét is megerősítheti az ENSZ Biztonsági Tanácsában, az Európai Unió ban, a NATO-ban, valamint az Amerikai Egyesült Államok szövetsé geseként. A tengerentúli terüileteinek köszönhetően Franciaország az USA után a világ második legnagyobb kizárólagos gazdasági övezeté vel rendelkezik (The Economist, 2016). 


\section{Külïgyi Szemle}

Új-Kaledónia függetlenedése a többi tengerentúli területre is ha tással lenne, legfőképpen a Csendes-óceánon, ahol a polinéz vezetők is a szeparációt támogatják. Párizs katonai jelenléte továbbra is tar tós és stabil Nouméában, hiszen államérdeke a térség biztonságának a fenntartása. Mint Emmanuel Macron jelezte, fokozott figyelmet szentelnek az indiai és a csendes-óceáni térségnek is, továbbá a Kína terjeszkedését akadályozó francia-indiai-ausztrál stratégiai tengely kialakításának a szükségességét hangsúlyozta (Vey, Rose és Grebler, 2018). Nouméa számára ez a francia jelenlét nemcsak gazdaságilag éri meg, de stabilitást és a fokozódó térségbeli versenytől védelmet is nyújt. Mindazonáltal fontos megemlíteni, hogy már nem Franciaország a szigetcsoport legnagyobb kereskedelmi partnere, Kína ugyanis háttérbe szorította (Mcdonald, 2020): a területről az export több mint 50 százaléka Kínába irányul. Új-Kaledónia egyik legfontosabb kihívá sa a jövőre nézve egyértelmúen a gazdasága diverzifikálása, azaz a nem kínai külföldi befektetőknek a szigetcsoportra vonzása lesz.

Bár Canberra hivatalosan semleges álláspontot képvisel Új-Kale dónia függetlenségi népszavazásával kapcsolatban, nem titok, hogy az ausztrál kormánynak érdeke a francia jelenlét fenntartása a szom szédságában, mivel a függetlenség kikiáltásának beláthatatlan követ kezményei lennének a tágabb csendes-óceáni térségben. Ausztráliá nak nagyon fontos, hogy olyan, megfelelő erőforrásokkal rendelkező nyugati szövetségese van a régióban, mint Franciaország, különösen mostanában, amikor geostratégiai változások zajlanak: az Egyesült Államok kivonul a térségből, közben viszont új szereplők csatlakoznának be a régió mindennapjaiba. A térség stabilitásának a fenntartása tehát kulcsfontosságú számára, ennek érdekében a dél-csendes-óce áni védelmi együttmúködésen alapuló stratégiai partnerségét is meg erősítette Párizzsal (Australian Government. Department of Foreign Affairs and Trade, 2017). A szigetcsoport potenciális függetlensége viszont veszélybe sodorhatja a Canberra és Párizs közötti védelmi megállapodást, amely az ausztrál haditengerészet számára hozzáférést biztosít a szigetcsoport francia katonai támaszpontjaihoz. Fontos hangsúlyozni, hogy a két ország regionális prioritásai nem egyeznek 
meg. Míg Franciaország stratégiai értéket és a globális vezetői törek vésének eszközét látja Új-Kaledóniában, addig Ausztráliának a régió stabilitása a legfontosabb (Firth, 2018).

Habár a kereskedelmet érintő szankciók ellenére e téren Auszt rália legjelentősebb partnere továbbra is Kína, ez utóbbi függ jobban a két ország közötti gazdasági kapcsolatoktól, tekintettel a déli kontinensről importált nyersanyag iránti igényére. A köztük lévő, egyre növekvő feszültség nem új keletű, azonban úgy tűnik, még tovább tud súlyosbodni a helyzet. Két felbontott szerződést, majd a régió védel mében folytatandó katonai fegyverkezés bejelentését követően Kína határozatlan időre felfüggesztette a magas szintű gazdasági egyez tetéseit a szigetországgal. A feszüiltségek kiéleződése közepette nem könnyű megtalálni a legmegfelelóbb retorikát Pekinggel szemben. De az Egyesült Államok szövetségeseként a régiós konfliktusok kezelését illetően Ausztrália és Új-Zéland hasonló álláspontot képvisel: közös nyilatkozatukban együttes erővel ítélték el a Dél-kínai-tengerrel kapcsolatos kínai „destabilizációs törekvéseket” (Hurst, 2021).

Annak ellenére, hogy a régió a Donald Trump által meghirdetett politika, az „America Firsl” során kevesebb figyelmet kapott, következésképpen meggyengültek az ottani szövetségi rendszerei, az Egye suilt Államok számára továbbra is egyértelmú prioritást élvez az IndoCsendes-óceán. A 2019-es kormányzati adatok szerint az Ázsiai és Csendes-óceáni Gazdasági Együttmúködés (Asia-Pacific Economic Cooperation, APEC) államaival folytatott kereskedelme meghaladta a 3,2 billió dollárt (Office of the United States Trade Representative, 2019), míg a régióba irányuló közvetlen küilföldi befektetéseinek az értéke 1,4 billió dollárt tett ki (Statista, 2019).

Egyelőre úgy tűnik, hogy kompromisszumok helyett Joe Biden is hasonló, feltartóztató külpolitikát tervez a régióban, s a legfontosabb biztonságpolitikai kockázatként Kínát jelölte meg. A kampánya alatt ígért, az ázsiai óriással szembeni kemény fellépést az elmúlt hóna pok eseményei is bizonyítják: az elődje által Kínára kivetett büntető vámokat nem oldotta fel, sőt további ottani cégek kapcsán vezetett be szankciókat, s továbbra is védi és fegyverekkel látja el Tajvant. Az 


\section{Külïgyi Szemle}

ázsiai NATO-nak is nevezett négyoldalú biztonsági együittműködés, a Quad (India, Japán, Ausztrália, USA) a központi eleme lesz Biden Ázsia-stratégiájának, amelynek célja Kína terjeszkedésének az ellensúlyozása.

Míg az USA-nak 56 hivatalos szövetségese van, addig Kína majdnem minden szomszédjával konfrontációba került már. A szövetségi rendszerei tekintetében elmarad Amerikától, de helyette beruházá sokkal és jelentős kereskedelmi partnerségek kiépítésén keresztül nö veli a globális gazdasági és politikai befolyását. Az utóbbi években így Kína nemesak jelentős és kikerülhetetlen kereskedelmi partnere lett a térségbeli országoknak, de Trump protekcionista gazdaságpolitikája sem kedvezett az amerikaiak ottani megitélésének. A gazdasági kapcso latai erősítése érdekében várhatóan újpra fog indulni az USA-nak az Átfogó és Előremutató Csendes-óceáni Partnerséghez (Comprehensive and Progressive Agreement for Trans-Pacific Partnership, CPTPP) való csatlakozásáról szóló dialógus. Ahhoz, hogy az Egyesült Államok szövetségesei hajlandóak legyenek fellépni Kínával szemben, nemcsak politikailag, de gazdaságilag is érdekeltnek kell lenniük. Így az USA sikere nagyban függ majd a kompromisszumra való készségétől - de egyelőre kérdéses, hogy mennyire tudja újradefiniálnia magát, és a multilateralizmus bajnokaként visszatérnie. Az azonban bizonyos, hogy a két ország közötti kiélezett versengés jelentős hatással lesz a térség politikai és gazdasági formálódására.

Peking a gazdasági és politikai térhódítása érdekében hatalmas beruházásokat valósít meg a térségben; az elmúlt évtizedben Ausztrália után a régió második legnagyobb támogatójává nőtte ki magát. A terjeszkedése fơ célja a stratégiai infrastruktúrák létrehozása, a he lyi erőforrások megszerzése, valamint a nemzetközi fórumokon való támogatottságának a növelése. A megfigyelések szerint elsősorban azokat a pénzhiánnyal küzdő országokat célozza meg, amelyek kevesebb francia támogatást és védelmet élveznek. A korábbi francia-brit kondomíniumba, az 1980-ban függetlenné vált Vanuatuba már jelen tős összegeket fektetett be. Az 54 millió dolláros kínai hitel segítségével megépített luganville-i kikötő, amelyet az ausztrál Lowy Intézet 
szerint azzal a szándékkal építettek, hogy nagy hadihajókat is tudjon fogadni (Radio New Zealand, 2018), jelenleg a legnagyobb csendesóceáni rakodópart. Habár a kínai és vanuatui kormány is határozottan tagadja a létesítmény katonaitámaszpont-jellegét (Wroe, 2018), a szomszédos országok és nagyhatalmak komoly aggodalmukat fejezték ki, és válaszul növelték a környező szigetállamok támogatását.

A kínai jelentét fokozódása miatt sokan attól tartanak, hogy egy független Új-Kaledónia az erőforrásai iránti szükségleteik következtében kiszolgáltatottá válik a terjeszkedő hatalmaknak, például Kínának - a lojális pártok a kampánystratégiájukat főleg e fenyegetés köré építették fel. Bár Új-Kaledóniát gazdaságilag visszavetné a francia támogatás elvesztése, a referendum eredményétől függetlenül is igaz, hogy a kínai kereskedelmi, turisztikai és beruházási kapcsola tok, illetve az ázsiai óriás által jelentett szilárd piac nélkül már szinte lehetetlen elképzelni a szigetcsoport jövőjét. 2018-ban Új-Kaledónia Kínába irányuló exportja 1,06 milliárd dollár volt, ez a terület kivitelének több mint 50 százaléka (Mcdonald, 2020). Pekingnek a jelenleg francia érdekeltség alá tartozó szigeten megmutatkozó, ilyen nagymértékűvé vált befolyása komolyan megkérdőjelezi a francia védelem és feltartóztatás hatékonyságát.

Új-Kaledónia azért is tölt be nagyon fontos szerepet a térségben, mert az elmúlt 30 évben a stabilitás mintapéldája volt - a zavargások visszatérése azonban a régióban is elkerülhetetlenül növelné a nyugtalanságot. A szigetcsoport jövőjének újradefiniálása egybeesik a csendes-óceáni térség stratégiai fejleményeivel, és amennyiben függetlenségre tesz szert, azzal reményt ad a térségbeli és a karib-tengeri területek szeparatista mozgalmainak, s ezzel súlyosan visszavetné Franciaország befolyását e régiókban.

Az aranyban és rézben gazdag Bougainville, amely $1700 \mathrm{~km}-\mathrm{re}$ fekszik Új-Kaledóniától északra, 2019-ben elsöprő többséggel, 98 százalékos támogatottsággal döntött a Pápua Új-Guineától való elszakadás mellett (Jorari és Doherty, 2020). Francia Polinézia sem örül a Franciaországtól való függésének, a 2004-es törvénymódosítások alkalmával ugyanis nem kapták meg maradéktalanul a célul kitűzött 


\section{Külïgyi Szemle}

autonómiákat (Mcdonald, 2020). Mindeközben Nyugat-Új-Guinea (Pápua) az Indonéziától, a jelentős katonai támaszponttal rendelkező Guam pedig az Egyesült Államoktól való függetlenedés lehetőségeit járja körül. A helyzetet az sem segíti, hogy Franciaország - a várakozásokkal ellentétben - még mindig csak szerény összeggel (évi százmillió dollárral) támogatja a térséget. A nagyhatalmi szerepe ellenére ez aránytalanul kevés az Ausztráliától érkező pénzügyi támogatáshoz (1,44 milliárd ausztrál dollár, azaz 1,08 milliárd amerikai dollár) képest (Australian Government, 2020), ami további feszültségeket okoz a térség egyik legfontosabb kormányközi szervezetén, a Csendes-óceáni Szigetek Fórumán (Pacific Islands Forum, PIF) belül is (Maclellan, 2016). A népszavazás eredményétől függetlenül - akár elszakad, akár szélesebb körű autonómiát szerez- Új-Kaledóniának meg kell határoznia a saját fejlődési stratégiáját, és meg kell erősítenie a kapcsolatait mind a szomszédos csendes-óceáni szigetállamokkal, mind pedig a regionális nagyhatalmakkal.

\section{Konklúzió}

A 2018-as és a 2020-as referendum eredménye jól tükrözi a társa dalmon belüli éles kontrasztot és a függetlenség ügye kapcsán to vábbra is fennálló mély etnikai megosztottságot. Az 1998-as egyez mény értelmében a harmadik választást 2021. december 12-re tűz ték ki, ám a függetlenségpártiak minimális győzelme sem jelentene valódi megoldást az új-kaledóniaiak problémájára. Márpedig annak ellenére, hogy a szavazásra nem jogosultak és a lojalisták egyiuttesen a sziget lakosságának több mint a felét alkotják, a helyiek jelentős része támogatni fogja a Francia Köztársaság elhagyását. Látszólag Új-Kaledónia füiggetlenségi népszavazása így zsákutcába vezet, s nem jelent valódi gyógyírt a több évtizedes sebekre - ez pedig Franciaország számára is megnehezíti, hogy pártatlan szervezője és megfigyelője legyen az önrendelkezési folyamatnak. A felek között a jövőbeni kormányzásról folytatandó párbeszéd kiemelt fontosságú a megbékélés szempontjából. 
A helyzetet tovább nehezíti a Covid19-járvány gerjesztette gazdasági bizonytalanság és visszaesés, a nikkelkészletek jövőbeli piacaival kapcsolatos aggályok, valamint a kínai kapcsolatok körüli nemzetközi feszültség. A következmények beláthatatlanok - mégpedig nemcsak Új-Kaledóniára nézve, de a tágabb régióra is -, miközben az új partnerségek stratégiai változásokat indítanak el a térségben. Franciaor szág számára kihívást fog jelenteni a szüikséges semlegesség megőrzése, ha meg akarja tartani Új-Kaledóniát és a többi tengerentúli területét. Nem csupán a stratégiai érdekeltségei forognak kockán, de a globális vezetôi szerepe is.

\section{Irodalomjegyzék}

APR Editor (2018). Blood in the Pacific: 30 Years on from the Ouvéa Island Cave Massacre. Asia Pacific Report. A letöltés ideje: 2021. június 8. https:/asiapacificreport.nz/2018/05/07/blood-in-the-pacific-30vears-on-from-the-ouvea-island-massacre/.

Australian Government (2020). Stepping-up Australia's Engagement with Our Pacific Family. A letöltés ideje: 2021. június 8. https:/www.dfat. gov.au/geo/pacific/engagement/Pages/stepping-up-australias-pacificengagement.

Australian Government. Department of Foreign Affairs and Trade (2017). Joint Statement of Enhanced Strategic Partnership Between Australia and France. A letöltés ideje: 2021. június 9. https://www.dfat.gov.au/ geo/france/Pages/joint-statement-of-enhanced-strategic-partnershipbetween-australia-and-france.

Australian Trade and Investment Commission (é. n.). Export Markets - New Caledonia. A letöltés ideje: 2021. június 15. https://www.austrade.gov.au/ australian/export/export-markets/countries/new-caledonia/industries.

Barrett, Jonathan (2021). New Caledonia's Government Collapses over Independence, Nickel Unrest. Reulers. A letöltés ideje: 2021. június 9. https://www.reuters.com/article/uk-newcaledonia-independencefrance/new-caledonias-government-collapses-over-independencenickel-unrest-idUKKBN2A30OH.

Commission de contrôle (2020). Résultats Définitifs. Référendum du 4 octobre 2020. Nouvelle-Calédonie. Haut-Commissariat de la 


\section{Külïgyi Szemle}

République Francaise. A letöltés ideje: 2021. június 9. http://www. nouvelle-caledonie.gouv.fr/content/download/6849/53341/file/ R\%C3\%A9f\%C3\%A9rendum $\% 20$ du $\% 204 \% 20$ octobre $\% 202020 \% 20-\% 20$ R\%C3\%A9sultat\%20d\%C3\%A9finitifs.pdf.

Dayant, Alexande (2018). New Caledonia's Independence Referendum Explained. Lowy Institule. A letöltés ideje: 2021. június 8. https:// www.lowvinstitute.org/the-interpreter/new-caledonia-independencereferendum-explained.

Dayant, Alexandre (2020a). New Caledonia: A Vote Lost, Yet Independence Advocates Claim a Win. Lowy Instilule. A letöltés ideje: 2021. június 9. https://www.lowvinstitute.org/the-interpreter/new-caledonia-votelost-vet-independence-advocates-claim-win.

Dayant, Alexandre (2020b). The Demographic Influence in New Caledonia's Next Referendum. Lowy Institule. A letöltés ideje: 2021. június 11. https:// www.lowvinstitute.org/the-interpreter/demographic-influence-newcaledonia-s-next-referendum.

Firth, Stewart (2018). Instability in the Pacific Islands: A Status Report. Lowy Institute. A letöltés ideje: 2021. június 9. https://www.lowvinstitute. org/publications/instability-pacific-islands-status-report.

Fisher, Denise (2013). France in the South Pacific. Canberra: Anu E Press. A letöltés ideje: 2021. június 9. https:/press-files.anu.edu.au/downloads/ press/p241101/pdf/book.pdf.

Fisher, Denise (2018). New Caledonia Prepares for Crucial Independence Vote. ASPI Strategist, Australian Strategic PolicyInstilute. A letöltés ideje: 2021. június 8. https://www.aspistrategist.org.au/new-caledoniaprepares-for-crucial-independence-vote.

Fisher, Denise (2020). Protests Over Mining and Independence Hit New Caledonia. ASPI Strategist. Australian Strategic Policy Institule. A letöltés ideje: 2021. június 12. https:/www.aspistrategist.org.au/protests-overmining-and-independence-hit-new-caledonia/.

France24 (2018). High Turnout As French Pacific Territory Votes on Independence. A letöltés ideje: 2021. június 8. https://www.france24. com/en/20181103-new-caledonia-polls-open-independencereferendum-vote-french-territorv-france.

Goulard, Sebastien (2018). New Caledonia: Moving Beyond the Independence Debate. The Diplomat. A letöltés ideje: 2021. június 8. https://thediplomat.com/2018/11/new-caledonia-moving-bevond-theindependence-debate/. 
Herlelendi Müvek (2021). Fémek, amelyek nélkül nem képzelhető el a jövő autóipara. A letöltés ideje: 2021. június 28. http://www.plasmatech.hu/ femek-amelyek-nelkul-nem-kepzelheto-el-a-jovo-autoipara.html.

Human Rights Council (2011). Report of the Special Rapporteur on the Rights of Indigenous Peoples, James Anaya. Addendum. The Situation of Kanak People in New Caledonia, France. A/HRC/18/35/Add.6. A letöltés ideje: 2021. június 10. https:/www.ohchr.org/Documents/ Issues/IPeoples/SR/A-HRC-18-35-Add6.pdf.

Hurst, Daniel (2021). China Accuses Morrison and Ardern of "Gross Interference' on Xinjiang and South China Sea. The Guardian. A letöltés ideje: 2021. június 15. https://www.theguardian.com/world/2021/jun/01/ china-accuses-morrison-and-ardern-of-gross-interference-onxinjiang-and-south-china-sea.

ICRA International (2018). Kanaky: Victoire du non au référendum sur l'autodétermination. A letöltés ideje: 2021. június 8. https://www. icrainternational.org/actualites/?post=kanakv-victoire-du-non-aureferendum-sur-lautodetermination.

ISEE (2019). Une mosaïque pluriethnique. ISEE Institul de la statistique el des éludes économique en Nouvelle Calédonie. A letöltés ideje: 2021. június 10. https://www.isee.nc/population/recensement/communautes.

Jeannin, Alain (2020). Nickel: les bons chiffres de la Nouvelle-Calédonie dans le grand bain de la mondialisation. FranceInfo. A letöltés ideje: 2021. június 16. https://alere.francetvinfo.fr/nouvellecaledonie/nickelles-bons-chiffres-de-la-nouvelle-caledonie-dans-le-grand-bain-de-lamondialisation-896962.html.

Jorari, Leanne és Doherty, Ben (2020). Bougainville Independence High on Agenda As Ishmael Toroama Elected President. The Guardian. A letöltés ideje: 2021. június 9. https://www.theguardian.com/world/2020/sep/23/ bougainville-independence-high-on-agenda-as-ishmael-toroamaelected-president.

Kelly, Lidia (2020). Voting Heavy in New Caledonia Referendum on Independence from France. Reuters. A letöltés ideje: 2021. június 12. https://www.reuters.com/article/newcaledonia-independence-franceidINKBN26P07M.

Maclellan, Nic (2016). France and the Forum. Inside Story. A letöltés ideje: 2021. június 10. https:/insidestory.org.au/france-and-the-forum. 


\section{Külïgyi Szemle}

Maclellan, Nic (2020). New Caledonia's Triple Opportunity. Inside Story. A letöltés ideje: 2021. június 14. https://insidestorv.org.au/new-caledoniastriple-opportunity.

Mcdonald, Joshua (2020). China's Shadow Looms As New Caledonia Decides Whether to Leave France. South China Morning Post. A letöltés ideje: 2021. június 10. https://www.scmp.com/week-asia/politics/ article $/ 3103562 /$ chinas-shadow-looms-new-caledonia-decideswhether-leave-france.

New Caledonia Travel (é. n.). Geography. A letöltés ideje: 2021. június 9. https://www.newcaledonia.travel/en/geographv.

OEC. The Observatory of Economic Complexity (2019). New Caledonia. A letöltés ideje: 2021. június 16. https://oec.world/en/profile/countrv/ncl.

Office of the United States Trade Representative (2019). U.S.-APEC Bilaterial Trade and Investment. A letöltés ideje: 2021. június 16. https:/ustr.gov/ countries-regions/japan-korea-apec/apec/us-apec-trade-facts.

Peteisi, Medriko (2020). Référendum: ces sondages qui restent confidentiels. France Tv Info. Nouvelle Calédonie lere. A letöltés ideje: 2021. június 12. https://alere.francetvinfo.fr/nouvellecaledonie/une-campagnepauvre-en-sondages-870716.html.

Pew Trusts (é. n.). New Caledonia, Pew Bertarelli Ocean Legacy. A letöltés ideje: 2021. június 8. https://www.pewtrusts.org/en/projects/pewbertarelli-ocean-legacy-new-caledonia.

Philippon, Laura és Gnipate, Steeven (2018). Des accords, une poignée de mains et un destin commun pour la Nouvelle-Calédonie. France Tv Info, La lere. A letöltés ideje: 2021. június 8. https://lalere.francetvinfo.fr/ accords-poignee-mains-destin-commun-nouvelle-caledonie-598687. html.

Radio New Zealand (2018). Speculation in Canberra at China's Plan for Vanuatu Wharf. A letöltés ideje: 2021. június 9. https:/www.rnz.co.nz/ international/pacific-news/354670/speculation-in-canberra-at-chinas-plan-for-vanuatu-wharf.

Radio New Zealand (2020). Concerns About Future of New Caledonia's SLN Deepen. A letöltés ideje: 2021. június 12. https://www.rnz.co.nz/ international/pacific-news/422546/concerns-about-future-of-newcaledonia-s-sln-deepen.

République Française, Légifrance (1958). Proclamation du 4 octobre 1958 des résultats des votes émis par le peuple français à l'occasion de 
sa consultation par voie de referendum. République Francaise. A letöltés ideje: 2021. június 8. https:/www.legifrance.gouv.fr/jorf/id/ JORFTEXT000000571394.

République Française, Légifrance (1998). Accord sur la Nouvelle-Calédonie signé à Nouméa le 5 mai 1998. Légifrance. A letöltés ideje: 2021. június 8. https:/www.legifrance.gouv.fr/jorf/id/JORFTEXT000000555817.

Roger, Patrick (2020). En Nouvelle-Calédonie, les clivages se creusent après le second référendum sur l'indépendance. Le Monde. A letöltés ideje: 2021. június 12. https://www.lemonde.fr/politique/article/2020/10/05 en-nouvelle-caledonie-les-clivages-se-creusent-apres-le-secondreferendum-sur-1-independance 6054808_823448.html.

Roger, Patrick (2021). Nouvelle-Calédonie: vers un ultime référendum sur l'indépendance avant la fin de l'année. Le Monde. A letöltés ideje: 2021. június 10. https://www.lemonde.fr/politique/article/2021/06/01/ nouvelle-caledonie-vers-un-ultime-referendum-sur-1-independanceavant-la-fin-de-1-annee_6082411_823448.html.

Sanderson, Henry (2021). Tesla to Become Adviser on Nickel Project in Bid to Secure Key Metal. Financial Times. A letöltés ideje: 2021. június 12. https://www.ft.com/content/fe508291-045b-4134-9089$4 \mathrm{~b} 650 \mathrm{c} 544 \mathrm{~d} 91$.

Statista (2019). Direct Investment Position of the United States in Asia Pacific from 2000 to 2019. A letöltés ideje: 2021. június 16. https:// www.statista.com/statistics/188604/united-states-direct-investmentsin-the-asia-pacific-region-since-2000/.

The Economist (2016). Daily Chart Drops in the Ocean: France's Marine Territories. A letöltés ideje: 2021. június 9. https:/wwww.economist. com/graphic-detail/2016/01/13/drops-in-the-ocean-frances-marineterritories.

Tromeur, Françoise (2019). Nouvelle-Calédonie: tout savoir sur le référendum de 2018. France Tv Info. Nouvelle Calédonie lere. A letöltés ideje: 2021. június 8. https://alere.francetvinfo.fr/nouvellecaledonie/longs-formatsil-y-an-referendum-767665.html.

Vey, Jean-Baptiste, Rose, Michel és Grebler, Dan (2018). Macron Wants Strategic Paris-Delhi-Canberra Axis Amid Pacific Tension. Reulers. A letöltés ideje: 2021. június 10. https:/www.reuters.com/article/usaustralia-france/macron-wants-strategic-paris-delhi-canberra-axisamid-pacific-tension-idUSKBN1I330F. 


\section{Külïgyi Szemle}

Winslow, Donna (1991). Land and Independence in New Caledonia. Cultural Survival. A letöltés ideje: 2021. június 10. https://www.culturalsurvival. org/publications/cultural-survival-quarterly/land-and-independencenew-caledonia.

Wroe, David (2018). The Great Wharf from China, Raising Eyebrows Across the Pacific. The Sydney Morning Herald. A letöltés ideje: 2021. június 13. https:/www.smh.com.au/politics/federal/the-great-wharffrom-china-raising-evebrows-across-the-pacific-20180411-p4z8vu. $\underline{\text { html. }}$. 